\title{
Bilateral scrotoschisis with crossed ectopy of the right testis
}

This article was published in the following Dove Press journal:

Open Access Surgery

20 February 2013

Number of times this article has been viewed

\section{Vincent C Onuora' \\ Eshiobo Irekpita' \\ Ugochukwu Alili' \\ Agbomherele Ajekweneh ${ }^{2}$ \\ Ihuoma N Amaechi'}

'Urology Unit, Department of Surgery,

${ }^{2}$ Department of Obstetrics and

Gynaecology, Irrua Specialist Teaching

Hospital, Irrua, Edo State, Nigeria
Correspondence: Vincent C Onuora Department of Surgery, ISTH,

PMB 0008, Irrua, Edo State, Nigeria

Email vconuora@gmail.com

\begin{abstract}
Scrotoschisis is an uncommon congenital anomaly in which the testis descends to an extracorporeal position through a defect in the scrotum. Bilateral scrotoschisis is extremely rare. We present a case of a 16-hour old neonate who was referred to our center with both testes protruding through a defect in the left hemiscrotum.
\end{abstract}

Keywords: bilateral scrotoschisis, crossed testicular ectopy

\section{Introduction}

The exact mechanism of testicular descent remains largely unknown. The influence of androgens, increase in intra-abdominal pressure, and the traction action of the gubernaculum all have their proponents. However, there is little controversy regarding the need for the testes to descend into the scrotum. Poor germ cell development, trauma, testicular torsion, and increased risks of malignant degeneration are recognized risks of cryptorchidism. Among the anomalies of testicular descent is extra-scrotal migration of the testis, a situation variously referred to as extrophy of the scrotum or scrotoschisis.

Recently, we managed a child in whom the right testicle migrated superior to the penis to exit the contralateral scrotum together with the left testis. We are not aware of any previous report of this type of anomaly and we report this case as our contribution to the continuing debate about the mechanism of testicular descent.

\section{Case report}

A neonate was brought to Irrua Specialist Teaching Hospital Irrua, Edo State, Nigeria, 16 hours after delivery with both testes protruding from the lateral aspect of his left scrotum. He was delivered at home by a 45-year-old mother with the assistance of her landlady. The delivery was uneventful. His mother had her antenatal care at a nearby primary health center but volunteered that she had also taken some herbal concoctions during the first trimester of her pregnancy.

The baby weighed $2.6 \mathrm{~kg}$ and was otherwise normal except in the urogenital system. Both testes and some lengths of the spermatic cord were extruded through a defect in the lateral aspect of the left scrotum (Figure 1). The right hemiscrotum was fully developed. Both scrotal sacs appeared inflamed as evidenced by a red and shiny skin.

He had antibiotic cover (ceftazidine and gentamicin) and tetanus toxoid. The scrotum was then cleaned and explored under general anesthesia. Both spermatic cords 


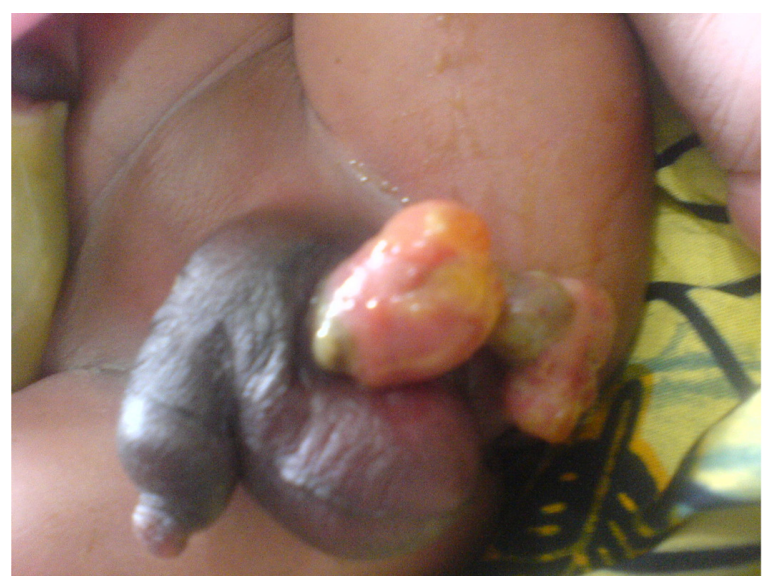

Figure I Both testes extruded through a defect in the left hemiscrotum. Note: Well developed scrotal sacs.

were traced up to their respective internal inguinal rings. The right testis had crossed to the left scrotal sac superior to the penis. Bilateral orchidopexy was done and the defect in the left scrotum was closed in two layers with no difficulty. The child has remained well and both testes were located in the appropriate scrotal sacs 3 months after the operation.

\section{Discussion}

There are many theories that attempt an explanation of the mechanism of testicular descent. Although John Hunter provided the first classical description of testicular descent over 200 years ago, ${ }^{1}$ the real mechanism of this process has not been satisfactorily resolved. Some research has suggested that the testicle is pulled down into the scrotum by the gubernaculum. ${ }^{2,3}$ Rajfer and Walsh believe that sufficient local and circulating androgens must be present to induce testicular descent. ${ }^{4}$ The intra-abdominal pressure theory states that elevated pressure within the peritoneal cavity pushes or forces the testes through the inguinal canal. ${ }^{5}$

No matter the mechanism of testicular descent however, scrotoschisis requires the development of a scrotal wall defect resulting in an ectopic extra-corporeal testicular descent. Gongaware et $\mathrm{al}^{6}$ suggested that failure or faulty differentiation of mesenchyme in the primitive scrotal swellings might lead to a scrotal wall defect through which the gonad migrates extra-corporeally. This theory has been challenged by others who pointed out that the testis could not be pulled down to an extra-corporeal site as there is no extra-scrotal anchor from which traction could be applied. ${ }^{7}$ Instead, they suggested that scrotoschisis is consistent with the pulsion concept of testicular descent. The fact that the right testis migrated superior to the penis and out of the left scrotum in our patient casts further doubt on the role of gubernaculum in testicular descent. Would the gubernaculum originating in the right scrotum pull the right testis to the left side?

It is generally taught that a scrotum that has not harbored a testis is usually hypoplastic. This is not the case in our index patient. The right scrotum was fully developed but empty. Maybe it is not the mere presence of the testis that induces adequate development of the scrotum. We opine that the same stimuli that initiate testicular descent may also stimulate scrotal sac development.

\section{Acknowledgment}

The parents of this patient gave permission for a picture of the anomaly to be published provided the child is not identifiable.

\section{Disclosure}

The authors report no conflicts of interest in this work.

\section{References}

1. Marshall FF, Elder JS, editors. Mechanisms of testicular descent. Cryptorchidism and Related Anomalies. New York, NY: Praeger Publishers; 1982:9-26

2. Lockwood CG. Development and transition of the testis, normal and abnormal. J Anat Physiol. 1888;22(Pt 4):505-541.

3. Lemeh CN. A study of the development and structural relationships of the testis and gubernaculum. Surg Gynecol Obstet. 1960;110:164-172.

4. Rajfer J, Walsh PC. Hormonal regulation of testicular descent: experimental and clinical observations. J Urol. 1977;118(6):985-990.

5. Elder JS, Isaacs JT, Walsh PC. Androgenic sensitivity of the gubernaculum testis: evidence for hormonal/mechanical interactions in testicular descent. J Urol. 1982;127(1):170-176.

6. Gongaware RD, Sussman AM, Kraebber DM, Michigan S. Scrotoschisis as a mechanism for extracorporeal testicular ectopia. J Pediatr Surg. 1991;26(12):1430-1431.

7. Hadley GP, Wiersma R. Scrotoschisis. Paediatr Surg Int. 1994;9: $148-149$.
Open Access Surgery

\section{Publish your work in this journal}

Open Access Surgery is an international, peer-reviewed, open access journal that focuses on all aspects of surgical procedures and interventions. Patient care around the peri-operative period and patient outcomes post surgery are key topics. All grades of surgery from minor cosmetic interventions to major surgical procedures are covered. Novel techniques

\section{Dovepress}

and the utilization of new instruments and materials, including implants and prostheses that optimize outcomes constitute major areas of interest. The manuscript management system is completely online and includes a very quick and fair peer-review system. Visit http://www.dovepress.com/ testimonials.php to read real quotes from published authors. 